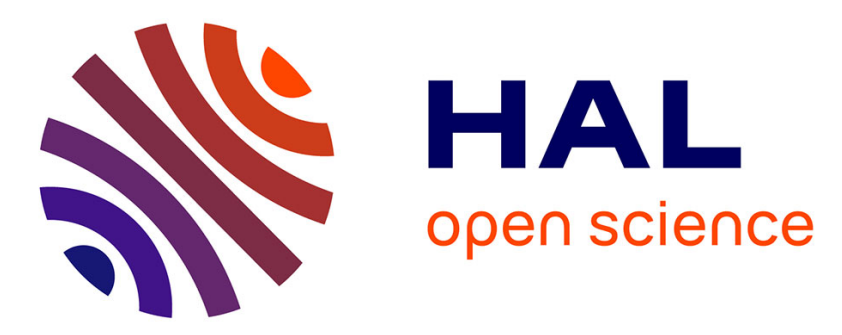

\title{
Study of uranium(VI) and radium(II) sorption at trace level on kaolinite using a multi-site ion exchange model
} Jacques Ly, Estela Reinoso-Maset

\section{To cite this version:}

Jacques Ly, Estela Reinoso-Maset. Study of uranium(VI) and radium(II) sorption at trace level on kaolinite using a multi-site ion exchange model. Journal of Environmental Radioactivity, 2016, 157, pp.136-148. 10.1016/j.jenvrad.2016.03.014 . cea-02382741

\section{HAL Id: cea-02382741 https://hal-cea.archives-ouvertes.fr/cea-02382741}

Submitted on 27 Nov 2019

HAL is a multi-disciplinary open access archive for the deposit and dissemination of scientific research documents, whether they are published or not. The documents may come from teaching and research institutions in France or abroad, or from public or private research centers.
L'archive ouverte pluridisciplinaire HAL, est destinée au dépôt et à la diffusion de documents scientifiques de niveau recherche, publiés ou non, émanant des établissements d'enseignement et de recherche français ou étrangers, des laboratoires publics ou privés. 


\title{
Study of uranium(VI) and radium(II) sorption at trace level on kaolinite using a multi-site ion exchange model
}

\author{
ESTELA REINOSO-MASET ${ }^{* 1}$ andJACQUES LY
}

CEA, Centre d'Etudes de Saclay, DANS/DPC/SECR/L3MR, 91191 Gif-sur-Yvette Cedex, France

*Corresponding author: E. Reinoso-Maset, email: estela.reinosomaset@gmail.com ;tel: +1209-228-4393; fax: +1-209-228-4158

${ }^{1}$ Present address:Sierra Nevada Research Institute,University of CaliforniaMerced, 5200

North Lake Road, Merced, CA 95343, USA

For submission to: Journal of Environmental Radioactivity 


\section{Highlights}

- sorption of trace $\mathrm{U}(\mathrm{VI})$ and $\mathrm{Ra}(\mathrm{II})$ on kaolinite was studied

- multi-site sorbent/multi-species sorbate ion exchange model used to describe sorption

- results provided U and Ra sorption equilibria stoichiometry and associated constants

- $\mathrm{Ra}^{2+}$ was the main adsorbed species over the $\mathrm{pH}$ range

- U negatively charged hydroxylated forms dominated sorption at $\mathrm{pH}>8$ 


\section{Abstract}

Uranium and the long-lived decay product radium-226 areabundantly present in mine wastes produced during uraniumextraction activities. In the case of release to thesurrounding environment, these radionuclides are attrace levels compared to groundwater solutes, and the presence, content and properties of clay minerals in these subsurface environments influence the extent of radionuclide sorption and, in turn, radionuclide migration. Since clays are known to havethe distinctive property of retaining ions, the aim of this work was to study the sorption of traceuranium(VI) and radium(II) on a common phyllosilicatemineral, kaolinite, in the presence of excess $\mathrm{K}$, a common groundwater cation, in order to obtain a thermodynamic database that describesthe ion-exchangeequilibria occurring at the mineral-solution interface.The sorption ofU(VI) and $\mathrm{Ra}(\mathrm{II})$ at trace level was obtainedfrom $\mathrm{pH} 2$ to 11 bymeasuring the distribution coefficient $\left(\mathrm{K}_{\mathrm{d}}\right)$, and additional sorption isotherms were carried out over a representative concentration range and at two different $\mathrm{pH}$. The sorption data for both elements was processedaccording to a general multi-site sorbent / multi-species sorbatemodel and provided fundamental sorption equilibria stoichiometryand associated equilibrium constants. Radium was sorbed from $\mathrm{pH} 2$ to 10.5 on two main sorption sites as $\mathrm{Ra}^{2+}$. U sorption was observed on all the sorption sites of kaolinite governed by its solution speciation,with positively charged hydroxylated species adsorbed between $\mathrm{pH} 2$ and 4, whereas its negatively charged forms dominated $\mathrm{U}$ sorption at $\mathrm{pH}>8$.

\section{Keywords}

Uranium(VI), radium, kaolinite, sorption, ion exchange

\section{Introduction}

Considerable large volumes of mill tailings are disposed every year near uranium mining sites(Abdelouas, 2006). Since most of the ore deposits have low uranium content, the mill tailings still comprise a small portion of the initial uranium and almost all of the daughter radionuclides of the ${ }^{238} \mathrm{U}$ decay series, including ${ }^{226} \mathrm{Ra}$ (Déjeant et al., 2014; Nirdosh et al., 1984). These decay products add to the environmental impactof uranium-waste, making the mill tailings to be considered low-level radioactive waste. In particular, ${ }^{226} \mathrm{Ra}$ is of notable relevance due to its long half-life (1600 y), degree of radiotoxicity and its short-lived 
31 decayproducts, such as gaseous ${ }^{222} \mathrm{Rn}$. The environmental concern of these tailings (and any 32 contaminated land) arises from the potentialreleaseof radionuclides into the groundwater, and, as a result, contamination of subsurface environments in the vicinity ofthe mine (Phrommavanh et al., 2013).

As thoroughly reviewed in Payne et al.(2013), a key factor on migration predictions is the extent of radionuclide sorption onto the surfaces of solid phases found in natural environments. These solid phases must be methodically characterised, with special emphasis on the identification of sorption sites, the estimation of their concentration and their sorption behaviour towards radionuclides under different conditions. The sorption of U(VI) and, in less extent, Rahave been previously studied for different iron oxyhydroxide, carbonate and clayey minerals(Catalano and Brown Jr, 2005; Jones et al., 2011; Payne et al., 2004; Sajih et al., 2014; Stammose et al., 1992; Tachi et al., 2001; Turner et al., 1996). Clay minerals are abundant in geological formations and soils, and have the distinctive property of retaining ions,with high affinity for cationic species.The sorption process on clays is mainly via ion exchange on the surface, becoming even more important with trace-level concentrations and low ionic strength conditions, as the onesin natural environments. Catalano and Brown Jr (2005)studied the sorption of $U$ on montmorillonite and observed that the fraction of uranyl sorbed via cation exchange under low ionic strength conditions was more important than observed in previous studies, where only surface complexation was considered. Turner et al. (1996)used an ion exchange model to describe sorption of uranyl on a smectite type clay, and obtained equilibrium constants for the different sorption sites on the surface. An ion exchange model (considering two types of sorption sites) was also more suitable than surface complexation model to describe the retention of U(VI) at trace level on a clay mixture of kaolinite and smectite (Stammose et al., 1992), and the sorption of Ra was also demonstrated to happen via an ion exchange mechanism on purified smectite (Tachi et al., 2001).

When radionuclides are found at trace or ultra-trace level, major cations (found at higher aqueous concentrations) are strong competitors for clay sorption sites in natural environments(Tertre et al., 2011). Therefore, a full characterisationof the clay properties towards the major ions is also required to describe the sorption of trace metals on clays. This

60 type of characterisation has already been carried out, for example, with argillaceous rock 61 (Motellier et al., 2003), beidellite(Robin et al., 2015)and kaolinite (Reinoso-Maset and Ly, 2014). In these three studies, the sorption of major ions was described using a multi-site ion 
exchange model, and provided with a comprehensive and robust sorption data setsthat can be applied when studying sorption of trace elements on these clays.

Therefore, the aim of this work was to study the sorption of trace level uranium(VI) and radium(II) on a common phyllosilicate mineral, kaolinite, in the presence of excess $\mathrm{K}$, a common groundwater cation, in order to determine the ion-exchange equilibria occurring at the mineral-solution interface. This work has followed a multi-site ion exchange model that can describe chemical systems such as a multi-site sorbent/multispecies sorbate, and which has already been applied in Reinoso-Maset and Ly (2014) to successfully characterise the ion exchange properties of the same kaolinite used in this work. The model is presented in detail therein, thus here we focused on the part of the model that describes sorption of a trace element. Following a detailed experimental protocol using chemical and radiochemical analytical techniques, batch experiments over a wide $\mathrm{pH}$ range (from 2 to 11)were carried out to measure the distribution coefficient $\left(\mathrm{K}_{\mathrm{d}}\right)$ of traceU(VI) and $\mathrm{Ra}(\mathrm{II})$ sorption on kaolinite. Additionally, sorption isotherms of both elements were measured over a representative concentration rangeand at two different solution $\mathrm{pH}$.Finally, to obtain fundamental sorption equilibria stoichiometry and associated constants, the sorption data for both elements was processed according to the ion exchange model described here.

\section{Methodology}

Reinoso-Maset and Ly (2014) obtained the type and concentration of sorption sites of the kaolinite used in this work, the related major ions sorption equilibria occurring at the mineralsolution interface and their associated selectivity coefficients (expressed as the corrected selectivity coefficients, $\left.K^{*}\right)$. The main formalisms and assumptions of the model are presenttherein, hence we have focused this section on the part of the model describing sorption of an element at trace level in the presence of two competitor ions.

\section{$\underline{2.1 \text { Adsorption on major sorption sites }}$}

The kaolinite crystal structure, $\mathrm{Al}_{2} \mathrm{Si}_{2} \mathrm{O}_{5}(\mathrm{OH})_{4}$, presents permanent negatively charged sites, $\mathrm{X}_{i}$, and hydroxylated sites with $\mathrm{pH}$-dependent charge, $\mathrm{Y}_{j} \mathrm{OH}$, that can result in different sorption equilibria occurring at the solid solution interface. When the element $\mathrm{M}$ is found at trace level compared to a major competitor $\mathrm{N}^{+}$and in the absence of other ligands than $\mathrm{OH}^{-}$, the adsorption of $\mathrm{M}$ on a major sorption site can occur under its free $\mathrm{M}^{m+}$ form or as one of its hydroxylated species, $\mathrm{M}(\mathrm{OH})_{\mathrm{x}}{ }^{\mathrm{m}-\mathrm{x}}$, depending on the solution $\mathrm{pH}$. 
Therefore, when considering $\mathrm{H}^{+}$as the reference competitor ion, the sorption of freeor

95 hydroxylated species of Mand $\mathrm{N}^{+}$on permanently charged sorption sites, $\mathrm{X}_{i}$, can be described by Equations 1 and 3 respectively. Their associated equilibrium constants (as the corrected selectivity coefficients) have the form of Equations 2 and 4.

$$
\begin{gathered}
\mathrm{M}^{m+}+p \overline{\mathrm{X}_{i}^{-} \mathrm{H}^{+}}+(m-p) \mathrm{H}_{2} \mathrm{O} \leftrightarrow \overline{\left(\mathrm{X}_{i}^{-}\right)_{p} \mathrm{M}(\mathrm{OH})_{m-p}^{p+}}+m \mathrm{H}^{+} \\
K_{\mathrm{M}(\mathrm{OH})_{m-p} / m \mathrm{H}}^{* i}=\frac{\left.\overline{\left(\mathrm{X}_{i}^{-}\right)_{p} \mathrm{M}(\mathrm{OH})_{m-p}^{p+}}\right]\left[\mathrm{H}^{+}\right]^{m}}{\left[\overline{\mathrm{X}_{i}^{-} \mathrm{H}^{+}}\right]^{p}\left[\mathrm{M}^{m+}\right]} \cdot \frac{\left(y_{\mathrm{H}}\right)^{m}}{y_{\mathrm{M}}} \\
\mathrm{N}^{+}+\overline{\mathrm{X}_{\mathrm{i}}^{-} \mathrm{H}^{+}} \leftrightarrow \overline{\mathrm{X}_{\mathrm{i}}^{-} \mathrm{N}^{+}}+\mathrm{H}^{+} \\
K_{\mathrm{N} / \mathrm{H}}^{* i}=\frac{\left[\overline{\left.\mathrm{X}_{\mathrm{i}}^{-} \mathrm{N}^{+}\right]\left[\mathrm{H}^{+}\right]} \cdot \frac{y_{\mathrm{H}}}{\left[\overline{\left.\mathrm{X}_{\mathrm{i}}^{-} \mathrm{H}^{+}\right]\left[\mathrm{N}^{+}\right]}\right.}\right.}{y_{\mathrm{N}}}
\end{gathered}
$$

where $K^{* i}$ is the corrected selectivity coefficient for $\mathrm{M}^{m+}$ or $\mathrm{N}^{+}$and $\mathrm{H}^{+}$exchange on a 99 surface site; $i$ is the index number of the surface site; $m$ is the cation charge $\overline{\left(\mathrm{X}_{i}^{-}\right)_{p} \mathrm{M}(\mathrm{OH})_{m-p}^{p+}}, \overline{\mathrm{X}_{\mathrm{i}}^{-} \mathrm{N}^{+}}$and $\overline{\mathrm{X}_{\mathrm{i}}^{-} \mathrm{H}^{+}}$are the chemical forms describing the sorption

101 state of $\mathrm{M}, \mathrm{N}$ and $\mathrm{H}^{+}$on site $\mathrm{X}_{i}$ respectively; the square brackets [ ] indicate the concentration 102 of species either in solution or adsorbed to site $\mathrm{X}_{i}$ (in $\mathrm{mol} \mathrm{L}^{-1}$ and $\mathrm{mmol} \mathrm{g}^{-1}$ of dry solid 103 respectively); and $y_{\mathrm{H}}, y_{\mathrm{M}}$ and $y_{\mathrm{N}}$ are the molar activity coefficients for $\mathrm{H}^{+}, \mathrm{M}^{m+}$ and $104 \mathrm{~N}^{+}$quantified in the present work according to Davies expression, $\log y_{i}=-0.5 \cdot \mathrm{z}_{\mathrm{i}}^{2}$. $105\left(\frac{\sqrt{I}}{1+\sqrt{I}}-0.3 \cdot I\right)$, with ionic strength $I=\frac{1}{2} \cdot \sum_{\mathrm{i}} \mathrm{C}_{\mathrm{i}} \mathrm{z}_{\mathrm{i}}^{2}$, where $\mathrm{C}_{\mathrm{i}}$ and $\mathrm{z}_{\mathrm{i}}$ are the molar concentration 106 and charge of the species $i$ respectively.

In the case of hydroxylated sorption sites, $\mathrm{Y}_{j} \mathrm{OH}$, the sorption of anions ( $\mathrm{L}^{-}$and anionic $\mathrm{M}$ 108 hydroxylated species) must be also considered. Equations from5 to 10showall the chemical 109 equilibria involved and their associated thermodynamic constants.

$$
\mathrm{N}^{+}+\overline{\mathrm{Y}_{j} \mathrm{OH}} \leftrightarrow \overline{\mathrm{Y}_{j} \mathrm{O}^{-} \mathrm{N}^{+}}+\mathrm{H}^{+}
$$




$$
\begin{gathered}
K_{\mathrm{N} / \mathrm{H}}^{* j}=\frac{\left[\overline{\left.\mathrm{Y}_{j} \mathrm{O}^{-} \mathrm{N}^{+}\right]}\left[\mathrm{H}^{+}\right]\right.}{\left[\overline{\mathrm{Y}_{j} \mathrm{OH}}\right]\left[\mathrm{N}^{+}\right]} \cdot \frac{y_{\mathrm{H}}}{y_{\mathrm{N}}} \\
\mathrm{L}^{-}+\overline{\mathrm{Y}_{j} \mathrm{OH}}+\mathrm{H}^{+} \leftrightarrow \overline{\mathrm{Y}_{j} \mathrm{OH}_{2}^{+} \mathrm{L}^{-}} \\
K_{\mathrm{L}}^{* j}=\frac{\left[\overline{\left.\mathrm{Y}_{j} \mathrm{OH}_{2}^{+} \mathrm{L}^{-}\right]}\right.}{\left[\overline{\mathrm{Y}_{j} \mathrm{OH}}\right]\left[\mathrm{L}^{-}\right]\left[\mathrm{H}^{+}\right]} \cdot \frac{1}{y_{\mathrm{L}} y_{\mathrm{H}}}
\end{gathered}
$$

-if $\mathrm{M}(\mathrm{OH})_{\mathrm{x}}^{\mathrm{m}-\mathrm{x}}$ are cationic species, $0 \leq \mathrm{x}=\mathrm{m}-\mathrm{p} \leq \mathrm{m}-1$ and $1 \leq \mathrm{p} \leq \mathrm{m}$, and thus:

$$
\mathrm{M}^{m+}+p \overline{\mathrm{Y}_{j} \mathrm{OH}}+(m-p) \mathrm{H}_{2} \mathrm{O} \leftrightarrow \overline{\left(\mathrm{Y}_{j} \mathrm{O}^{-}\right)_{p} \mathrm{M}(\mathrm{OH})_{m-p}^{p+}}+m \mathrm{H}^{+}
$$

-if $\mathrm{M}(\mathrm{OH})_{\mathrm{x}}^{\mathrm{m} \cdot \mathrm{x}}$ are anionic species, $\mathrm{x}>\mathrm{m}$ and $\mathrm{q} \geq 1$, and thus:

$$
\mathrm{M}^{m+}+q \overline{\mathrm{Y}_{j} \mathrm{OH}}+m \mathrm{H}_{2} \mathrm{O} \leftrightarrow \overline{\left(\mathrm{Y}_{j}\right)_{q} \mathrm{M}(\mathrm{OH})_{m+q}}+m \mathrm{H}^{+}
$$

110 Since the exchange reactions ofthe element $\mathrm{M}$ are in competition with the ones involving $111 \mathrm{~N}^{+}$, as well as $\mathrm{L}^{-}$, the total concentration of sites $\mathrm{X}_{i}$ and $\mathrm{Y}_{j} \mathrm{OH}\left(\mathrm{SC}_{i}\right.$ and $\mathrm{SC}_{j}$ respectively) will 112 be given by Equation 11 and 12.

$$
\begin{gathered}
\mathrm{SC}_{i}=\left[\overline{\mathrm{X}_{i}^{-} \mathrm{H}^{+}}\right]+\left[\overline{\mathrm{X}_{i}^{-} \mathrm{N}^{+}}\right]+\sum_{p=m}^{1} p\left[\overline{\left(\mathrm{X}_{i}^{-}\right)_{p} \mathrm{M}(\mathrm{OH})_{m-p}^{p+}}\right] \\
\mathrm{SC}_{j}=\left[\overline{\mathrm{Y}_{j} \mathrm{OH}}\right]+\left[\overline{\mathrm{Y}_{j} \mathrm{O}^{-} \mathrm{N}^{+}}\right]+\left[\overline{\mathrm{Y}_{j} \mathrm{OH}_{2}^{+} \mathrm{L}^{-}}\right]+\sum_{p=m}^{1} p\left[\overline{\left(\mathrm{Y}_{j} \mathrm{O}^{-}\right)_{p} \mathrm{M}(\mathrm{OH})_{m-p}^{p+}}\right] \\
+\sum_{q \geq 1} q\left[\overline{\left(\mathrm{Y}_{j}\right)_{q} \mathrm{M}(\mathrm{OH})_{m+q}}\right]
\end{gathered}
$$

113 However, the concentration of sites occupied by the trace metal M (either in Equation 11 114 or 12) can be considered negligible respect to the concentration of sites with adsorbed $\mathrm{H}^{+}, \mathrm{N}^{+}$ 115 and $\mathrm{L}^{-}$, and thus the distribution coefficient of the element $\mathrm{M}\left(\mathrm{K}_{\mathrm{d}_{\mathrm{M}}}=[\overline{\mathrm{M}}] /[\mathrm{M}]\right)$ canbe 116 expressed as a function of the corrected selectivity coefficients of $\mathrm{M}, \mathrm{N}$ and $\mathrm{L}$, the 
117 concentration of sites $i$ and $j(\mathrm{SC} i$ and $\mathrm{SC} j$ ) and the solution $\mathrm{pH}$ by combining Equations 2, 4, 118 6, 811 and 12. The final mathematical development yields to Equation 13.

$$
\begin{aligned}
& \mathrm{K}_{\mathrm{d}_{\mathrm{M}}}=\frac{1}{\alpha_{\mathrm{M}} \cdot\left[\mathrm{H}^{+}\right]^{m} \cdot \frac{\left(y_{\mathrm{H}}\right)^{m}}{y_{\mathrm{M}}}} \cdot\left(\sum_{\text {sites }} \sum_{i} \frac{K_{\mathrm{M}(\mathrm{OH})_{m-p} / m \mathrm{H}}^{* i} \cdot\left(\mathrm{SC}_{i}\right)^{p}}{\left(1+K_{\mathrm{N} / \mathrm{H}}^{* i} \cdot \frac{\left[\mathrm{N}^{+}\right]}{\left[\mathrm{H}^{+}\right]} \cdot \frac{y_{\mathrm{N}}}{y_{\mathrm{H}}}\right)^{p}}\right. \\
& +\sum_{\text {sites }}\left[\sum_{p=m}^{1} \frac{K_{\mathrm{M}(\mathrm{OH})_{m-p} / m \mathrm{H}}^{* j} \cdot\left(\mathrm{SC}_{j}\right)^{p}}{\left(1+K_{\mathrm{N} / \mathrm{H}}^{* j} \cdot \frac{\left[\mathrm{N}^{+}\right]}{\left[\mathrm{H}^{+}\right]} \cdot \frac{y_{\mathrm{N}}}{y_{\mathrm{H}}}+K_{\mathrm{L}}^{* j} \cdot\left[\mathrm{L}^{-}\right] \cdot\left[\mathrm{H}^{+}\right] \cdot y_{\mathrm{L}} \cdot y_{\mathrm{H}}\right)^{p}}\right. \\
& \left.+\sum_{q \geq 1} \frac{K_{\mathrm{M}(\mathrm{OH})_{m+q} / m \mathrm{H}}^{* j} \cdot\left(\mathrm{SC}_{j}\right)^{q}}{\left.\left(1+K_{\mathrm{N} / \mathrm{H}}^{* j} \cdot \frac{\left[\mathrm{N}^{+}\right]}{\left[\mathrm{H}^{+}\right]} \cdot \frac{y_{\mathrm{N}}}{y_{\mathrm{H}}}+K_{\mathrm{L}}^{* j} \cdot\left[\mathrm{L}^{-}\right] \cdot\left[\mathrm{H}^{+}\right] \cdot y_{\mathrm{L}} \cdot y_{\mathrm{H}}\right)^{q}\right]}\right)
\end{aligned}
$$

119 where $\alpha_{M}$ is the overall side-reaction coefficient expressed as

$$
\alpha_{\mathrm{M}}=\frac{[\mathrm{M}]_{\text {total }}}{\left[\mathrm{M}^{m+}\right]}=1+\sum_{r} \frac{\beta_{r}}{\left[\mathrm{H}^{+}\right]^{r}}+\sum_{s} \beta_{s} \cdot\left[\mathrm{L}^{l-}\right]^{s}
$$

120 toaccount for the aqueous chemical equilibria, including the complexation of $\mathrm{M}$ by hydroxide

121 ion(effective formation constant $\beta_{\mathrm{r}}$ ) and ligands $\mathrm{L}^{1-}$ (effective formation constants $\beta_{\mathrm{s}}$ ). The 122 reactions and constants to calculate the side-reaction coefficient for $\mathrm{U}$ and $\mathrm{Ra}$ in this work are 123 shown in the Supplementary Information, Table S1.

124 If the terms in Equation 13 that are independent to $i$ and $j$ are arranged with the $\mathrm{K}_{\mathrm{d}}$, an 125 equation with the form of a $\mathrm{Y}=F(\mathrm{X}, \mathrm{Z})$ function can be obtained (Equation 14):

$$
\begin{aligned}
\mathbf{Y}=\log \left(\sum_{\text {sites }} \sum_{i} \sum_{p=m}^{1} \frac{K_{\mathrm{M}(\mathrm{OH})_{m-p} / m \mathrm{H}}^{* i} \cdot\left(\mathrm{SC}_{i}\right)^{p}}{\left(1+K_{\mathrm{N} / \mathrm{H}}^{* i} \cdot 10^{\mathbf{X}}\right)^{p}}\right. \\
+\sum_{\text {sites } \mathrm{j}}\left[\sum_{p=m}^{1} \frac{K_{\mathrm{M}(\mathrm{OH})_{m-p} / m \mathrm{H}}^{* j} \cdot\left(\mathrm{SC}_{j}\right)^{p}}{\left(1+K_{\mathrm{N} / \mathrm{H}}^{* j} \cdot 10^{\mathbf{X}}+K_{L}^{* j} \cdot 10^{\mathbf{z}}\right)^{p}}\right. \\
\left.\left.+\sum_{q \geq 1} \frac{K_{\mathrm{M}(\mathrm{OH})_{m+q} / m \mathrm{H}}^{* j} \cdot\left(\mathrm{SC}_{j}\right)^{q}}{\left(1+K_{\mathrm{N} / \mathrm{H}}^{* j} \cdot 10^{\mathbf{X}}+K_{L}^{* j} \cdot 10^{\mathrm{Z}}\right)^{q}}\right]\right)
\end{aligned}
$$


127 (Equations 15-17).

$$
\begin{gathered}
\mathbf{Y}=\log \left(\mathrm{K}_{\mathrm{d}_{\mathrm{M}}} \cdot \alpha_{\mathrm{M}} \cdot\left[\mathrm{H}^{+}\right]^{\mathrm{m}} \cdot \frac{\left(y_{\mathrm{H}}\right)^{\mathrm{m}}}{y_{M}}\right) \\
\mathbf{X}=\log \left(\frac{\left[\mathrm{N}^{+}\right]}{\left[\mathrm{H}^{+}\right]} \cdot \frac{y_{\mathrm{N}}}{y_{\mathrm{H}}}\right) \\
\mathbf{Z}=\log \left(\left[\mathrm{L}^{-}\right] \cdot\left[\mathrm{H}^{+}\right] \cdot y_{\mathrm{L}} \cdot y_{\mathrm{H}}\right)
\end{gathered}
$$

128

130

134 horizontal asymptotefor the $\mathbf{Y}_{\mathrm{i}(\mathrm{p})}=f_{\mathrm{i}(\mathrm{p})}(\mathbf{X})$ curve that allows estimating the value of the 135 corrected selectivity coefficient for $\mathrm{M} \quad\left(K^{* i}\right)$. When $\mathbf{X} \rightarrow+\infty$, then $\mathbf{Y}_{\mathrm{i}(\mathrm{p}) \rightarrow \log }$ $136\left[\frac{K_{\mathrm{M}(\mathrm{OH})_{m-p} / \mathrm{H}^{*} \cdot\left(\mathrm{SC}_{i}\right)^{p}}^{*_{i}}}{\left(K_{\mathrm{N} / \mathrm{H}}^{*}\right)^{p}}\right]-p \cdot \mathbf{X}$, which isa linear asymptote with negative slopeindependently of the 137 value of $p$, always a positive number $(1 \leq p \leq m)$. This slope provides the stoichiometry of the 138

Equation 14 is a logarithm of a sum of different terms describing the following possible sorption processes occurring in the system:

- cation adsorption on permanently charged sites $X_{i}$

$$
\mathrm{Y}_{\mathrm{i}(\mathrm{p})}=\log \left[\frac{K_{\mathrm{M}(\mathrm{OH})_{m-p} / \mathrm{H}}^{*_{i}} \cdot\left(\mathrm{SC}_{i}\right)^{p}}{\left(1+K_{\mathrm{N} / \mathrm{H}}^{*} \cdot 10^{\mathrm{X}}\right)^{p}}\right]=f_{i(p)}(\mathbf{X})
$$

- cation adsorption on hydroxylated sites $\mathrm{Y}_{\mathrm{j}} \mathrm{OH}$

$$
\mathrm{Y}_{\mathrm{j}(\mathrm{p})}=\log \left[\frac{K_{\mathrm{M}(\mathrm{OH})_{m-p} / \mathrm{H}}^{* j} \cdot\left(\mathrm{SC}_{j}\right)^{p}}{\left(1+K_{\mathrm{N} / \mathrm{H}}^{* j} \cdot 10^{\mathrm{X}}+K_{\mathrm{L}}^{* j} \cdot 10^{\mathrm{Z}}\right)^{p}}\right]=f_{i(p)}(\mathbf{X}, \mathbf{Z})
$$

- anion adsorption on hydroxylated sites $\mathrm{Y}_{\mathrm{j}} \mathrm{OH}$

$$
\mathrm{Y}_{\mathrm{j}(\mathrm{q})}=\log \left[\frac{K_{\mathrm{M}(\mathrm{OH})_{m+p} / \mathrm{OH}}^{* j} \cdot\left(\mathrm{SC}_{j}\right)^{q}}{\left(1+K_{\mathrm{N} / \mathrm{H}}^{* j} \cdot 10^{\mathrm{X}}+K_{\mathrm{L}}^{* j} \cdot 10^{\mathrm{Z}}\right)^{q}}\right]=f_{j(q)}(\mathbf{X}, \mathbf{Z})
$$

Therefore, when $\mathbf{X} \rightarrow-\infty$, then $\mathbf{Y}_{\mathrm{i}(\mathrm{p})} \rightarrow \log \left(K_{\mathrm{M}(\mathrm{OH})_{m-p} / \mathrm{H}}^{* i} \cdot\left(\mathrm{SC}_{i}\right)^{p}\right)$, which results in a adsorbed species and the associated chemical equilibrium. 
In the same way, andif $\mathrm{K}_{\mathrm{N} / \mathrm{H}}^{* \mathrm{j}} \cdot 10^{\mathbf{X}} \gg \mathrm{K}_{\mathrm{L}}^{* \mathrm{j}} \cdot 10^{\mathbf{Z}}, \mathbf{Y}_{\mathrm{j}(\mathrm{p})} \rightarrow \log \left[\frac{K_{\mathrm{M}(\mathrm{OH})_{m-p} / \mathrm{H}^{*}}^{*_{\mathrm{j}}} \cdot\left(\mathrm{SC}_{\mathrm{j}}\right)^{p}}{\left(K_{\mathrm{N} / \mathrm{H}}^{* j}\right)^{p}}\right]-p \cdot \mathbf{X}$ and $\mathbf{Y}_{\mathrm{j}(\mathrm{q})}$

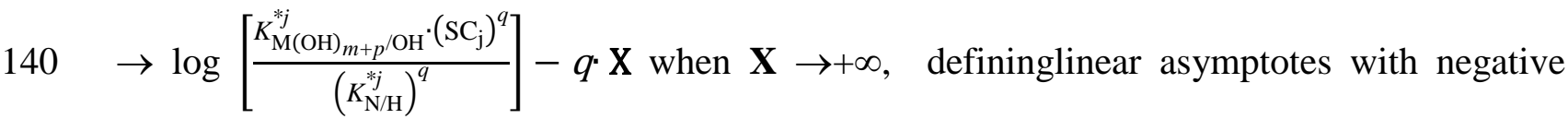

141 slopes $(1 \leq p \leq m$ and $q \geq 1)$. Since $\mathbf{X}$ and $\mathbf{Z}$ vary in the opposite direction with increasing $\mathrm{pH}$

142 (see Equations 16 and 17), the increase of $\mathbf{Y}$ with $\mathbf{X}$ (i.e. positive slope of the curve $\mathrm{Y}=f(\mathrm{X})$ )

143 implies that $\mathrm{K}_{\mathrm{N} / \mathrm{H}}^{* \mathrm{j}} \cdot 10^{\mathrm{X}} \ll \mathrm{K}_{\mathrm{L}}^{* \mathrm{j}} \cdot 10^{\mathrm{Z}}$, which gives evidence of hydroxylated sorption sites that are

144 able to absorb anionic species of $\mathrm{M}$.

145 The curves $\mathrm{Y}=f(\mathrm{X})$ and $\mathrm{Y}=g(\mathrm{Z})$ can be obtained experimentally by determining the 146 distribution coefficient of $\mathrm{M}$ in the presence of excess $\mathrm{N}^{+}$over a wide $\mathrm{pH}$ range. The 147 commonly used $\mathrm{K}_{\mathrm{d}}$ vs. $\mathrm{pH}$ curve can then be converted to $\mathrm{Y}=f(\mathrm{X})$ and $\mathrm{Y}=g(\mathrm{Z})$ curves 148 representation, where the charge of the adsorbed species $p$ and $q$ can be determined through 149 the slopes of the curves, which consequently allows to write the stoichiometry of the sorption 150 reaction for the trace element $\mathrm{M}$ (Equations 1, 9or 10). The corrected selectivity coefficient

151 associated to the reaction on each sorption site, $K_{\mathrm{M}(\mathrm{OH})_{m-p} / \mathrm{H}}^{* i}, K_{\mathrm{M}(\mathrm{OH})_{m-p} / \mathrm{H}}^{* j}$ and $K_{\mathrm{M}(\mathrm{OH})_{m+p} / \mathrm{OH}}^{* j}$, 152 can be obtained by nonlinear fitting of the experimental data. The values of $\mathrm{SC}_{i}, \mathrm{SC}_{j}$ and $K_{\mathrm{N} / \mathrm{H}}^{* i}$, $153 K_{\mathrm{N} / \mathrm{H}}^{* j}, \mathrm{~K}_{\mathrm{L}}^{* j}$ need to be determined a priori from saturation curves of major cations and anions 154 over $\mathrm{pH}$. The clay material used in Reinoso-Maset and Ly (2014)is the same as the one used 155 in this work, therefore site concentrations and stability constants obtained therein were used in 156 the calculations presented here (see discussion).

\section{$157 \quad 2.2$ Adsorption on minor sorption sites}

158 Minor sorption sites $\left(<0.001 \mathrm{mmol} \mathrm{g}^{-1}\right.$ of dry clay) can have a significant affinity for elements at trace level.Reinoso-Maset and Ly(2014) identified one minor sorption site on the kaolinite after performing adsorption isotherms of Cs over a concentration range, at constant $\mathrm{pH}$ and excess of $\mathrm{Na}^{+}$in solution (i.e. a competitor ion for the sorption sites). Therein, the methodology and equations for the sorption of monovalent cations is fully explained. In this work, the trace elements are present in solution mainly as their doubly charged species. The equation to calculate the total adsorbed concentration, $[\overline{\mathrm{M}}]_{\mathrm{T}}$, of a doubly charged elementM in the presence of a monovalent competitor cation can be derived in the same manner and has the final form of Equation 18. 


$$
\begin{aligned}
& {[\overline{\mathrm{M}}]_{\mathrm{T}}=\sum_{i=1}^{\mathrm{n}}\left[\overline{\left(\mathrm{X}_{\mathrm{i}}^{-}\right)_{2} \mathrm{M}^{2+}}\right]=} \\
& =\sum_{i=1}^{\mathrm{n}}\left(\frac{\mathrm{SC}_{i}}{2}+\frac{\left(1+K_{\mathrm{N} / \mathrm{H}}^{* i} \cdot \frac{\left[\mathrm{N}^{+}\right]}{\left[\mathrm{H}^{+}\right]} \cdot \frac{y_{\mathrm{N}}}{y_{\mathrm{H}}}\right)^{2}}{8 \cdot K_{\mathrm{M} / \mathrm{H}}^{* i} \cdot \frac{\left[\mathrm{M}^{2+}\right]}{\left[\mathrm{H}^{+}\right]^{2}} \cdot \frac{y_{\mathrm{M}}}{\left(y_{\mathrm{H}}\right)^{2}}}\right.
\end{aligned}
$$

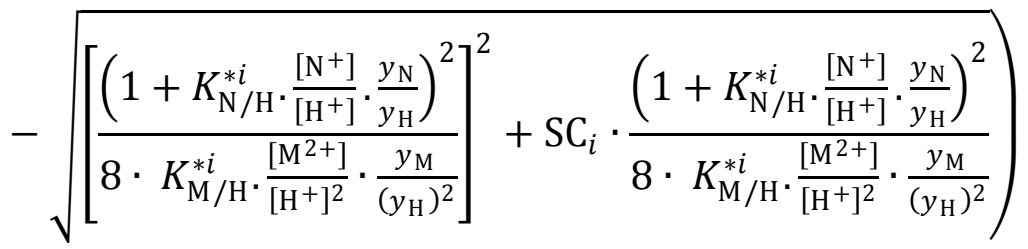

167

This equation can then be used, along with the measured $M$ concentration in solution at equilibrium, $[M]$, to obtain the distribution coefficient $\left(K_{d}\right)$ of the element $M$. Ata given $p H$ and constant $\mathrm{N}^{+}$concentration, and providing thatM is at trace level compared to the concentration of sites, $[\bar{M}]_{T}$ changes proportionally to $[M]$ and thus the $K_{d}$ tends to a constant value. When $[\overline{\mathrm{M}}]_{\mathrm{T}}$ reaches the concentration of minor sorption sites, $\mathrm{SC}_{s}$, a pronounced decrease of $K_{d}$ towards 0 occurs due to full saturation of the sorption sites. In Equation 18, the solution $\mathrm{pH}$ and concentrations can be obtained experimentally, whereas the values of $\mathrm{SC}_{i}$ and $K_{\mathrm{N} / \mathrm{H}}^{* i}$ were determined from the cation saturation curves over $\mathrm{pH}$ in Reinoso-Maset and Ly (2014). By performing a nonlinear fitting of the adsorption isotherms $\left(\log \mathrm{K}_{\mathrm{d}} \mathrm{vs} . \log [\overline{\mathrm{M}}]_{\mathrm{T}}\right)$, the corrected selectivity coefficients associated to the adsorption equilibria reactions on minor sorption sites can be calculated.

\section{Materials and methods}

\section{$\underline{3.1 \text { Reagents and solutions }}$}

All solutions were prepared with ultrapure water $\left(18.2 \mathrm{M} \Omega \cdot \mathrm{cm}^{-1}\right.$, Milli-Q gradient system, Millipore) and analytical grade reagentspurchased from Sigma Aldrich (USA), Fisher Scientific (UK), Fluka (Germany) or VWR (France).Solid phase masses and solution volumes were always determined by weight using daily calibrated 4 decimal figure balances (Mettler Toledo AT200 or XP504, France). Experiments were carried out at room temperature and atmospheric $\mathrm{CO}_{2}$, except for the preparation of $\mathrm{K}$ hydroxide solutions (used to adjust the $\mathrm{pH}$ 
of the clay suspensions) which was carried out in $\mathrm{CO}_{2}$-free conditions to minimise additional complexation processes.

Radioisotopes solutions of ${ }^{232} \mathrm{U}$ and ${ }^{226} \mathrm{Ra}$ were obtained from Isotope Products Laboratories (USA). Due to the relatively short half-life of ${ }^{232} U\left(t_{1 / 2}=68.9\right.$ years), the formation of decay products (i.e. ${ }^{228} \mathrm{Th},{ }^{224} \mathrm{Ra},{ }^{220} \mathrm{Rn}$, etc.) can cause interferences in the activity counting, therefore the source solution was firstpurifiedfollowing the methodology proposed by Kraus et al. (1956). Analiquot of the ${ }^{232} \mathrm{U}$ source solution wasloaded in an ion exchange resin column (AG1X8, 100-200 mesh, chloride form; Biorad Laboratories, USA)pre-conditioned with $8 \mathrm{M} \mathrm{HCl}$. The decay products were washed out using $8 \mathrm{M} \mathrm{HCl}$, and to recover the more strongly retained ${ }^{232} \mathrm{U}$, the column was rinsed with $0.1 \mathrm{M} \mathrm{HCl}$. The eluted solution was neutralised with a small volume of $4 \mathrm{M} \mathrm{KOH}$. This fresh ${ }^{232} \mathrm{U}$ spiking solution was used within 21 days to ensure that less than $2 \%$ of the total activity was due to the accumulated decay products. In the case of ${ }^{226} \mathrm{Ra}\left(\mathrm{t}_{1 / 2}=1600\right.$ years), the source and spiking solutions were aerated under the fume hood before sampling to avoid any external contamination by the daughter gas ${ }^{222} \mathrm{Rn}\left(\mathrm{t}_{1 / 2}=3.825\right.$ days). The formation of other decay products was not an issue for the type of experiments carried out in this study.

\subsection{Clay preparation}

The kaolinite clay mineral used in the workwas $100 \%$ wt. pure kaolinite purchased from Sigma-Aldrich (Germany). Its purity was verified by X-ray diffraction and its $\mathrm{N}_{2}$-BET specific surface area was $21.38 \mathrm{~m}^{2} \mathrm{~g}^{-1}$ (Reinoso-Maset and Ly, 2014). Prior to the batch experiments, the raw pure kaolinite was conditioned to its $\mathrm{K}$ homoionic form as explained in detail in (Reinoso-Maset and Ly, 2014).Briefly, raw kaolinite was first homoionized to Nakaolinite and then converted to K-kaolinite. A MilliQ water suspension was carried out to eliminate any residual salt solution, and a final ethanol suspension was used to enhance the drying process. The homoionic K-kaolinite was then gently ground to fine powder and stored in a constant relative humidity container until use. The water content calculated after drying few $\mathrm{mg}$ at $105^{\circ} \mathrm{C}$ was less than $1.30 \%$ and considered for the actual mass involved in each individual batch.

\subsection{Adsorption over pH experiments}

The adsorption of $\mathrm{U}(\mathrm{VI})$ and $\mathrm{Ra}(\mathrm{II})$ at trace level was studied at room temperature for a $\mathrm{pH}$ range between 2 and 12in the presence of excess $\mathrm{K}$. The $\mathrm{U}$ and Ra distribution coefficients weredeterminedusing $0.1 \mathrm{~g}$ of $\mathrm{K}$-kaolinite and $20 \mathrm{~mL}$ solution phase in tightly capped $30 \mathrm{~mL}$ 
218 Nalgene centrifuge tubes.This experimental configuration offered a minimal headspace and 219 when sampling was needed the exposure to the laboratory air was for a short time, thus 220 limiting the introduction of atmospheric $\mathrm{CO}_{2}$ to a negligible amount. In addition, other 221 potential sources of air $\mathrm{CO}_{2}$ were prevented, e.g. $\mathrm{KOH}$ was prepared in a glove-box and added 222 to clay suspensions via an automatic burette.

223 In order too fully disperse and hydrate the clay material, itwas first suspended with 224 MilliQ waterand after $>16 \mathrm{~h}$ aliquots of $\mathrm{KClO}_{4}$ solution were added accordinglyto obtain5 $\cdot 10^{-}$ $225{ }^{2}$ M K.The potassium perchlorate saltwas used to avoid any potential complexation of $\mathrm{U}$ or $\mathrm{Ra}$ 226 by the salt anion.After $>16 \mathrm{~h}$ equilibration time, the $\mathrm{pH}$ was adjusted with known aliquots of 227 concentrate $\mathrm{HClO}_{4}$ and $\mathrm{KOH}$ (previously determined by titration of an equivalent clay amount)and suspensions were shaken for $>20 \mathrm{~h}$, a sufficient time to reach thermodynamic equilibrium between solid and solution phases. The final solution $\mathrm{pH}$ was measured after phase separation by ultracentrifugation (20 min, $20000 \mathrm{rpm}$ ), and two $1 \mathrm{~mL}$ and one $5 \mathrm{~mL}$ supernatant aliquots were collected for anion, cation and dissolved Si analysis.

At this stage, an aliquot of known ${ }^{232} \mathrm{U}$ and ${ }^{226} \mathrm{Ra}$ activitywas added to each batch suspensions, corresponding to initial $\mathrm{U}$ and $\mathrm{Ra}$ concentrations of ca. $10^{-9}$ and $10^{-10} \mathrm{M}$ respectively. In both cases, the spiked suspensions were equilibrated overnight on a TURBULA orbital mixer before solid and solution phases were separated by ultracentrifugation. A 1 mLaliquot of the supernatant was taken from uranium batch experiments for liquid scintillation counting (LSC) and $10 \mathrm{~mL}$ aliquot from $\mathrm{Ra}$ batch experiments forgamma spectrometry. Based on the isotopic dilution principle of nofractionation between stable and radioactive $\mathrm{M}$, determining thesupernatant activityis a simple approach to measure the distribution ratio between solid and solution phases, and consequently the concentration of adsorbed U or Ra (Reinoso-Maset and Ly, 2014).

\subsection{Adsorption isotherm experiments}

The $\mathrm{U}(\mathrm{VI})$ and $\mathrm{Ra}(\mathrm{II})$ adsorption isotherms were obtained at two given $\mathrm{pH}$ using $0.15 \mathrm{~g}$ of $244 \mathrm{~K}$-kaolinite. Buffer solutions of $2.5 \cdot 10^{-3} \mathrm{M} \mathrm{KOH}$ and $5 \cdot 10^{-3} \mathrm{M}$ 2-[N-morpholine]ethanesulfonic acid (MES) or 3-[cyclohexylamino]-1-propane-sulfonic-acid (CAPS) were used to

246 fix the solution $\mathrm{pH}$ at 6.1 and 10.2 respectively. These reagents are known to have no 247 interaction with metallic elements (Yu et al., 1997) and their anionic forms are unlikely to be 248 adsorbed onto the clay surface, therefore, they will not interfere with the ion exchange 249 reactions. The buffer solutions also contained $5 \cdot 10^{-2} \mathrm{M} \mathrm{KClO}_{4}$ to provide excess $\mathrm{K}$ in solution. 
In order to avoid $\mathrm{pH}$ changes during the adsorption process, the K-kaolinite was first washed with $20 \mathrm{~mL}$ of buffer solutions. The suspensions were mixed during $1 \mathrm{~h}$ and after ultracentrifugation (20 min, $20000 \mathrm{rpm}$ ) the supernatant was carefully removed to avoid clay loss. The buffer solution wash was repeated one more time. A final $20 \mathrm{~mL}$ buffer solution was used to equilibrate the system overnight. Clay dissolution and $\mathrm{K}$ concentration were checked after ultracentrifugation (20 min, $20000 \mathrm{rpm}$ ) by sampling $5 \mathrm{~mL}$ of the supernatant for Sianalysis, and two $0.1 \mathrm{~mL}$ aliquots for cation and anion determination.

In the $U$ batch experiments, and without exceeding the solubility limit of $U$ at each $\mathrm{pH}$ value, aliquots of stable $U$ stock solutions prepared from an ICP-AES standard solution (1000 $\mu \mathrm{g} \mathrm{mL}^{-1} \mathrm{U}$ in $4 \% \mathrm{HNO}_{3}$, PlasmaCAL, SCP Science, Canada) were added to the suspensions to obtain 10 concentrations between $2 \cdot 10^{-10}$ and $1 \cdot 10^{-7} \mathrm{M}$ for the MES series ( $\mathrm{pH} 6.1$ ), and 12 concentrations up to $1.26 \cdot 10^{-6} \mathrm{M}$ for the CAPS series ( $\mathrm{pH} 10.4$ ). The suspensions were placed on an orbital shaker and left to equilibrate for $>20 \mathrm{~h}$. Both series were finally spiked with 200 $\mu \mathrm{L}$ of ${ }^{232} \mathrm{U}$ spiking solution prepared as described above. The additionof ${ }^{232} \mathrm{U}$ was taken into account in the total $\mathrm{U}$ concentration in solution.Stable Ra salts or solutions are not available, thusthe concentration range in the Ra batch experiments was obtained from a ${ }^{226} \mathrm{Ra}$ spiking solution. The added activities corresponded to an initial Ra concentration between $1.82 \cdot 10^{-10}$

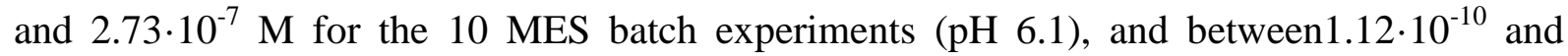
$3.47 \cdot 10^{-7} \mathrm{M}$ for the 10 CAPS batch experiments ( $\mathrm{pH}$ 10.4). In both set of experiments, the spiked suspensions were shaken overnight on a TURBULA mixer before solution and solid phases were separated by ultracentrifugation (20 min, $20000 \mathrm{rpm}$ ) and 1 and $10 \mathrm{~mL}$ aliquots were taken for ${ }^{232} \mathrm{U}$ LSCand ${ }^{226} \mathrm{Ra}$ gamma spectrometry respectively.

\subsection{Analytical methodology and experimental error}

The solution $\mathrm{pH}$, cation and anion concentration by ion chromatography and dissolved silicon concentration by UV-Vis spectrometry were determined in the exact same manner as the methodology followed in Reinoso-Masetand Ly (2014) and analytical details are explained therein.

The activity of ${ }^{232} \mathrm{U}$ was measured on a Tri-CARB $2700 \mathrm{TR}$ liquid scintillation analyser (Packard, USA) using the $\alpha / \beta$ discrimination mode to verifythat the activity is originated by a pure $\alpha$ emitter. Since the batch series contained high concentration of salt buffer solutions, 0.3

$280 \mathrm{~mL}$ supernatant aliquots were diluted with $0.7 \mathrm{~mL}$ of acetate buffer $(0.3 \mathrm{M}$ final 281 concentration) before mixing with $4 \mathrm{~mL}$ scintillation cocktail. This resulted in an equal 
quenching level for all samples with a constant counting efficiency. The counting was performed during 15 min and only the $\alpha$ emission band $(200-400 \mathrm{keV})$ was considered.

The $\gamma$ activity of $10 \mathrm{~mL}$ supernatant aliquots containing ${ }^{226} \mathrm{Ra}$ was determined using a gamma spectrometer equipped with an N-type coaxial high purity germanium detector (ITECH-Instruments). The gamma spectra were collected from 0 to $2000 \mathrm{keV}$ during $60 \mathrm{~min}$ and treated with the InterWinner 6.0 software. The ${ }^{226} \mathrm{Ra}$ band was identified at $186 \mathrm{keV}$. This band coincides with the ${ }^{235} U$ energy band, but since $U$ was not present in these batch solutions, any registered activity at this specific energy was attributed to the Ra isotope.

The uncertainties reported in this work were calculated for each experimental batch by the propagation of known measurement errors theory,as explained in detail inReinosoMasetand Ly(2014).

\section{Results and discussion}

\subsection{Adsorption of $U$ and Ra over $p H$}

The $\mathrm{K}_{\mathrm{d}}$ distribution for trace $\mathrm{U}$ and $\mathrm{Ra}$ sorption on $\mathrm{K}$-kaolinite was obtained over $\mathrm{pH}$ in the presence of excess $\mathrm{K}$ (Figure 1). The $\mathrm{U}$ data shows a sorption edge at around $\mathrm{pH} 3.5$ followed by a wide sorption plateau, that ends with a slight $\mathrm{K}_{\mathrm{d}}$ increase and another two short sorption edges are seen at the highest $\mathrm{pH}$ range of the experiments $(\mathrm{pH} 10-11)$. Radium however was completely adsorbed at the highest $\mathrm{pH}$, causing null $\mathrm{K}_{\mathrm{d}}$ results and thus the data points above $\mathrm{pH}$ 10.6were excluded from the curve representation. Negligible sorption was observed below $\mathrm{pH} 4$, resulting in $\mathrm{K}_{\mathrm{d}}$ values around 0 . This data is shown in the graph for reference, but it was not considered in the data treatment. Between $\mathrm{pH} 4$ and 10 , the $\mathrm{K}_{\mathrm{d}}$ increased gradually with increasing $\mathrm{pH}$, as expected from the exchange reaction. However, these results in this form do not provide further information about the charge of the adsorbed species nor the stoichiometry of the reaction.Therefore, the experimental $\mathrm{K}_{\mathrm{d}}$ data was transformed to the $\mathrm{Y}=f(\mathrm{X})$ and $\mathrm{Y}=g(\mathrm{Z})$ functions and $\mathrm{Y}$ was represented against $\mathrm{X}$ for both trace U and Ra sorption (Figure 1).

In the case of $\mathrm{U}$, a small plateau is observed at $1<\mathrm{X}<2.5$, followed by a decrease of the curve with slope between -2 and -1 , for then, at $X>6$, increase with +1 and +2 slope up to $X$ $=10$. The positive slope observed in the $\mathrm{Y}=f(\mathrm{X})$ could be due to the precipitation of uranyl silicate minerals formed with $\mathrm{Si}$ brought into solution by the inevitable dissolution of kaolinite. However, special care was taken when choosing the $U$ concentration for these 
experiments, by working with considerable low total concentration of the radioisotope. The non-precipitation was confirmed by the total $\mathrm{U}$ in solution at equilibrium for each experimental batch falling below the calculated limiting solubility curves for three $U$ mineral phases at the experimental conditions (Figure S1in SI). Another consideration is the formation of uranyl carbonate species. Payne et al. (2004) studied the sorption of U over the $\mathrm{pH}$ on two Georgia kaolinites and observed that at $\mathrm{pH}>8$ the complexation of $\mathrm{U}$ by dissolved carbonate reduced the $\mathrm{U}$ uptake. It was elsewhere mentioned that uranyl carbonate species could be adsorbed on another clay mineral surface, montmorillonite(Catalano and Brown Jr, 2005). Both studies, however, were conducted on air-equilibrated clay suspensions, i.e. systems containing more than about $10^{-5} \mathrm{M}$ total dissolved carbonate. According to thermodynamic predictions, this dissolved concentration will exponentially increase at $\mathrm{pH}$ higher than 5.5 (Figure S2 in SI) and would explain the observed uranium reactivity. As mentioned above, in this work the amount of carbonate involved in each experiment was sufficiently small to prevent a significant formation of uranyl carbonate complexes. Therefore, the positive slopes were assigned to the sorption of negative uranyl species according with the dissolved species distribution in the absence of carbonate, which shows thatthe main speciesat $\mathrm{pH}>8$ are $\mathrm{UO}_{2}(\mathrm{OH})_{3}{ }^{-}$and $\mathrm{UO}_{2}(\mathrm{OH})_{4}{ }^{2-}{ }^{-}$(Figure $\mathrm{S} 3$ in SI).

The $\mathrm{Y}=f(\mathrm{X})$ representation for Ra shows a curve with two linear parts $(1<\mathrm{X}<7$ and 7 $<X<9$ ) both with slope -2 , corresponding to a positively doubly charged species being adsorbed on two different sorption sites. This speciation of Ra agrees with previous studies (e.g. Sajih et al. (2014)) and with its solution speciation distribution of Ra, which is dominated by $\mathrm{Ra}^{2+}$ up to $\mathrm{pH} 11.5$ in the absence of carbonate or any other complexing agent (Figure S3 in SI).

Once the charge of the adsorbed specieswere deduced, a nonlinear fitting of the $\mathrm{Y}=F(\mathrm{X}$, Z) representation for both $U$ and $\mathrm{Ra}$ adsorption was performed using Equation 14. The number and concentration ofsorption sites on the kaolinite, as well as the constants describing the ion exchange reaction for the major cation and anion ( $\mathrm{K}$ and $\mathrm{ClO}_{4}$ in these experiments) were obtained inour previous work (Reinoso-Maset and Ly, 2014). Briefly, cation and anion saturation curves revealed five major sorption sites on the kaolinite surface, of which two were identified as permanently charged sites $\left(\mathrm{X}_{3}^{-}, \mathrm{X}_{4}^{-}\right)$and three as hydroxylated sorption sites $\left(\mathrm{Y}_{1} \mathrm{OH}, \mathrm{Y}_{2} \mathrm{OH}, \mathrm{Y}_{5} \mathrm{OH}\right)$. The sorption isotherms confirmed the presence of a minor sorption site of lower concentration but higher affinity. Table S2 in SI shows all the solution species, sorption sites and equilibrium constants used to resolve Equation 14 for each 
system.After some trial and error fittings with all the possibilities, the calculated curves were simplified to the sum of the curves corresponding only to the sorption equilibria that contributed most at each $\mathrm{pH}$ interval (e.g. the sorption of negative uranyl species at low $\mathrm{pH}$ was negligible compared to the positively charged species). The $\mathrm{Y}=F(\mathrm{X}, \mathrm{Z})$ fittings for $\mathrm{U}$ and Ra were optimized by nonlinear regression using Excel Solver tool and are represented in Figure 2.The stability constants, as corrected selectivity coefficients, obtained from the optimized fittings are summarised in Table 1 . These corrected selectivity coefficients for $\mathrm{U}$ and $\mathrm{Ra}$, along with constants previously obtained for $\mathrm{K}, \mathrm{ClO}_{4}$ and sorption site concentrations (Reinoso-Maset and Ly, 2014)were subsequently used in Equation 13 to fit the $\log \mathrm{K}_{\mathrm{d}} \mathrm{vs.} \mathrm{pH}$ graphs (Figure 1 for raw data). Figure 2 shows the individual curves for each $\mathrm{U}$ and $\mathrm{Ra}$ species as well as the overall calculated $\mathrm{K}_{\mathrm{d}}$ curve.

For $\mathrm{U}$, the sorption of the free uranyl $\left(\mathrm{UO}_{2}{ }^{2+}\right)$ was dominant at $\mathrm{pH}<5$ on sorption site $\mathrm{Y}_{2} \mathrm{OH}$ but also presented considerable sorption on $\mathrm{X}_{4}$ at circumneutralpH. The positively charged hydroxylated form, $\mathrm{UO}_{2}(\mathrm{OH})^{+}$, adsorbed mainly on site $\mathrm{X}_{3}$. The negatively charged species, $\mathrm{UO}_{2}(\mathrm{OH})_{3}{ }^{-}$and $\mathrm{UO}_{2}(\mathrm{OH})_{4}{ }^{2-}$, were the predominant species adsorbed on site $\mathrm{Y}_{5} \mathrm{OH}$ at $\mathrm{pH}>7$. This distribution of the adsorbed species over $\mathrm{pH}$ highly agrees with the speciation in solution (Figure S2 in SI), and the overall calculated $\mathrm{K}_{\mathrm{d}}$ curve fits satisfactorilywell to the experimental data (see comparison of calculated vs experimental data in Figure 1).In the case of $\mathrm{Ra}$, the lower number of experimental points limited the fitting to only few possible modelling assumptions. Despite higher uncertainty (see calculated vs experimental in Figure 1 ), the fitting reveals that the sorption of $\mathrm{Ra}^{2+}$ over $\mathrm{pH}$ occurred more importantly on sites $\mathrm{Y}_{2} \mathrm{OH}$ and $\mathrm{X}_{4}$, behaviour that resembles the sorption of divalent cations, $\mathrm{Ca}$ and $\mathrm{Mg}$, on the same kaolinite material(Reinoso-Maset and Ly, 2014).

\subsection{Adsorption isotherms of $U$ and $R a$}

Figure 3 shows the experimental adsorption isotherms of $\mathrm{U}$ and $\mathrm{Ra}$ at trace level at $\mathrm{pH}$ 6.1 and 10.4. Regardless the variability on the $\mathrm{pH} 10.4$ series for $\mathrm{U}$, a significant difference on the coefficient distribution was observed between the different $\mathrm{pH}$ series. This difference was more remarkable between the $\mathrm{Ra}$ series, demonstrating that as the $\mathrm{pH}$ increases higher sorption is observed, as seen in the saturation curves.

For both elements and both $\mathrm{pH}$ series, a decrease of sorption at around $\log [\mathrm{M}]=-4.5$ mmol $\mathrm{g}^{-1}$ proves the existence of a low concentration site, which was saturated as the concentration of $\mathrm{U}$ or $\mathrm{Ra}$ increased in solution. Since all series showed the same inflexion 
point, the concentration of this site is hence independent of the solution $\mathrm{pH}$ and solution speciation. Moreover, this estimated concentration $\left(0.082 \mu \mathrm{mol} \mathrm{g}^{-1}\right)$ agrees with the minor site $\left(\mathrm{X}_{\mathrm{s}}\right)$ identified on the Cs isotherm in Reinoso-Maset and Ly (2014). Therefore, at the time of calculating the $\mathrm{U}$ and $\mathrm{Ra}$ isotherm curves by non-linear fitting, this value was used to determine the contribution of a minor site on the overall $U$ and Ra sorption. In both cases, the contribution of a major site (i.e. $\mathrm{Y}_{1} \mathrm{OH}$ ) was also taken in account, along with the corrected selectivity coefficients for $\mathrm{K}$ that had been obtained in previous experiments(Reinoso-Maset and Ly, 2014).

The calculated isotherms curves are shown in Figure 3. For trace $\mathrm{U}$ at both $\mathrm{pH}$ and $\mathrm{Ra}$ at $\mathrm{pH} 10.4$, the major contribution to the sorption was by the minor site, $\mathrm{X}_{\mathrm{s}}$, while for $\mathrm{Ra}$ at $\mathrm{pH}$ 6.1 the major site, $\mathrm{Y}_{1} \mathrm{OH}$, had a significant contribution to the sorption. From the non-linear fitting, the best estimated of the corrected selectivity coefficients for $U$ and Ra sorption on the minor site $\mathrm{X}_{\mathrm{S}}$ were calculated as well as the $\mathrm{U}$ sorption on site $\mathrm{Y}_{1} \mathrm{OH}$, which had not been revealed in the saturation curve (Table 2). The comparison of calculated and experimental $\mathrm{K}_{\mathrm{d}}$ values shows a satisfactory agreement for both elements (Figure 3). model presented here provided with extra information about the speciation of sorbed $U$ and $\mathrm{Ra}$ at trace level on kaolinite over a wide $\mathrm{pH}$ range. Moreover, the thermodynamic constants of the sorption equilibria were also obtained during optimisation of the model. Table 3 compiles the chemical equilibria for $\mathrm{U}$ and $\mathrm{Ra}$ and their associate equilibrium constants (as corrected selectivity coefficients). $\mathrm{Ra}$ was sorbed as its free form, $\mathrm{Ra}^{2+}$, from $\mathrm{pH} 2$ to 10.5 on two main sorption sites, comparably to the behaviour of $\mathrm{Ca}$ and $\mathrm{Mg}$ sorption on kaolinite. Uranium, on the other hand, showed a more complicated speciation with positively charged species (free and hydroxylated forms) dominating the sorption at $\mathrm{pH}$ below 7 , while negatively charged uranyl species were sorbed at higher $\mathrm{pHs}$ on the most basic sorption site. The sorption isotherms proved the existence of minor sites, which have lower concentration but high affinity for elements at trace level concentrations.

The sorption equilibria and associated constants reported here complete the major ions sorption equilibria obtained previously (Reinoso-Maset and Ly, 2014) and consolidate the multi-site ion exchange model as a reliable approach to obtain a robust thermodynamic 
kaolinite, and in any other similar multi-site ion exchanger. Consequently, this fundamental thermodynamic database will improve the knowledge on radionuclide behaviour in environments containing clayey minerals, which are extremelyrelevant for migration predictions at contaminate sites.

\section{Acknowledgements}

This research was partially funded by AREVA Mines Direction R\&D under Contract number A-NOPRA-02-03.

\section{References}

Abdelouas, A., 2006. Uranium Mill Tailings: Geochemistry, Mineralogy, and Environmental Impact. Elements 2, 335-341.

Catalano, J.G., Brown Jr, G.E., 2005. Uranyl adsorption onto montmorillonite: Evaluation of binding sites and carbonate complexation. Geochim. Cosmochim. Acta 69, 2995-3005.

Déjeant, A., Bourva, L., Sia, R., Galoisy, L., Calas, G., Phrommavanh, V., Descostes, M., 2014. Field analyses of $238 \mathrm{U}$ and 226Ra in two uranium mill tailings piles from Niger using portable HPGe detector. J. Environ. Radioact. 137, 105-112.

Jones, M.J., Butchins, L.J., Charnock, J.M., Pattrick, R.A.D., Small, J.S., Vaughan, D.J., Wincott, P.L., Livens, F.R., 2011. Reactions of radium and barium with the surfaces of carbonate minerals. Appl. Geochem. 26, 1231-1238.

Kraus, K.A., Moore, G.E., Nelson, F., 1956. Anion-exchange studies. XXI. Th(IV) and U(IV) in hydrochloric acid. Separation of thorium, protactinium and uranium. J. Am. Chem. Soc. 78, 2692-2695.

Motellier, S., Ly, J., Gorgeon, L., Charles, Y., Hainos, D., Meier, P., Page, J., 2003. Modelling of the ion-exchange properties and indirect determination of the interstitial water composition of an argillaceous rock. Application to the Callovo-Oxfordian low-water-content formation. Appl. Geochem. 18, 1517-1530.

Nirdosh, I., Muthuswami, S.V., Baird, M.H.I., 1984. Radium in uranium mill tailings - Some observations on retention and removal. Hydrometallurgy 12, 151-176.

Payne, T.E., Brendler, V., Ochs, M., Baeyens, B., Brown, P.L., Davis, J.A., Ekberg, C., Kulik, D.A., Lutzenkirchen, J., Missana, T., Tachi, Y., Van Loon, L.R., Altmann, S., 2013. Guidelines for thermodynamic sorption modelling in the context of radioactive waste disposal. Environmental Modelling \& Software 42, 143-156. 
Payne, T.E., Davis, J.A., Lumpkin, G.R., Chisari, R., Waite, T.D., 2004. Surface

Phrommavanh, V., Leermakers, M., de Boissezon, H., Nos, J., Koko, M.-B., Descostes, M., 2013. Characterizing the Transport of Natural Uranium and its Decay Product 226Ra, Downstream from Former Mines in France. Procedia Earth and Planetary Science 7, 693-696.

Reinoso-Maset, E., Ly, J., 2014. Study of major ions sorption equilibria to characterize the ion exchange properties of kaolinite. J. Chem. Eng. Data 59, 4000-4009.

Robin, V., Tertre, E., Beaufort, D., Regnault, O., Sardini, P., Descostes, M., 2015. Ion 451 exchange reactions of major inorganic cations $\left(\mathrm{H}^{+}, \mathrm{Na}^{+}, \mathrm{Ca}^{2+}, \mathrm{Mg}^{2+}\right.$ and $\left.\mathrm{K}^{+}\right)$on beidellite: Experimental results and new thermodynamic database. Toward a better prediction of contaminant mobility in natural environments. Appl. Geochem. 59, 74-84.

Sajih, M., Bryan, N.D., Livens, F.R., Vaughan, D.J., Descostes, M., Phrommavanh, V., Nos, J., Morris, K., 2014. Adsorption of radium and barium on goethite and ferrihydrite: A kinetic and surface complexation modelling study. Geochim. Cosmochim. Acta 146, 150-163.

Stammose, D., Ly, J., Pitsch, H., Dolo, J.M., 1992. Sorption mechanisms of three actinides on a clayey mineral. Appl. Clay Sci. 7, 225-238.

Tachi, Y., Shibutani, T., Sato, H., Yui, M., 2001. Experimental and modeling studies on sorption and diffusion of radium in bentonite. J. Contam. Hydrol. 47, 171-186.

Tertre, E., Prêt, D., Ferrage, E., 2011. Influence of the ionic strength and solid/solution ratio on $\mathrm{Ca}$ (II)-for-Na+ exchange on montmorillonite. Part 1: Chemical measurements, thermodynamic modeling and potential implications for trace elements geochemistry. J. Colloid Interface Sci. 353, 248-256.

Turner, G.D., Zachara, J.M., McKinley, J.P., Smith, S.C., 1996. Surface-charge properties and $\mathrm{UO}_{2}{ }^{2+}$ adsorption of a subsurface smectite. Geochim. Cosmochim. Acta 60, 3399-3414.

467 Yu, Q., Kandegedara, A., Xu, Y., Rorabacher, D.B., 1997. Avoiding Interferences from 468 Good's Buffers: A Contiguous Series of Noncomplexing Tertiary Amine Buffers Covering the 469 Entire Range of pH 3-11. Anal. Biochem. 253, 50-56. 


\section{Figures}

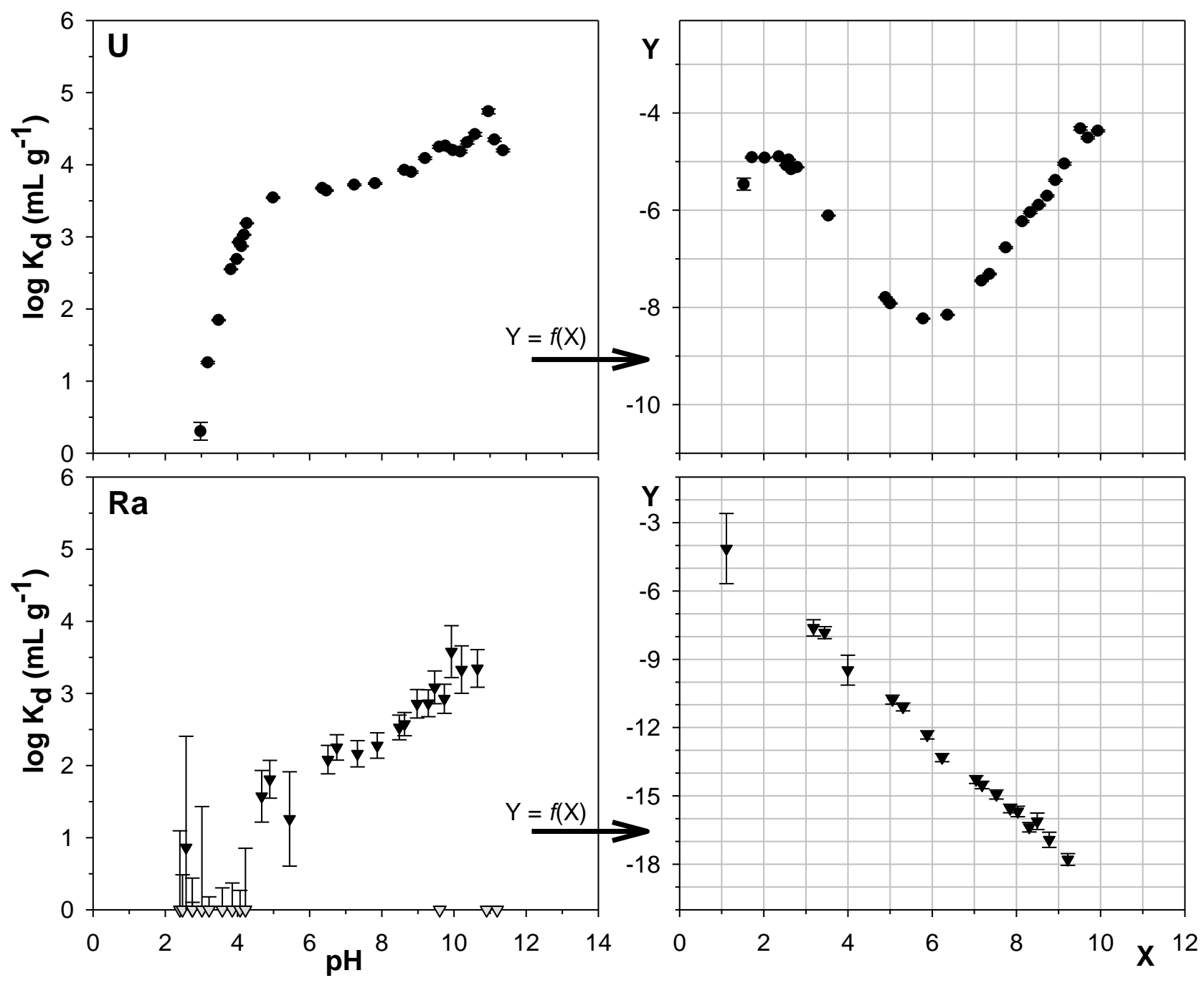

Figure 1. Left:Experimental distribution coefficient $\left(\mathrm{K}_{\mathrm{d}}\right)$ over pHfor $\mathrm{U}$ (top) and Ra (bottom) sorption on K-kaolinite in the presence of $5 \cdot 10^{-2} \mathrm{M}$ K. Grey triangles were excluded for further data analysis. Right: $\mathrm{Y}=f(\mathrm{X})$ representation of the same $\mathrm{U}$ and Ra sorption data following Equation 14. Grey lines are 1:1 grids to help visualize the slopes. In all cases, the error bars represent $\pm 1 \sigma$. 


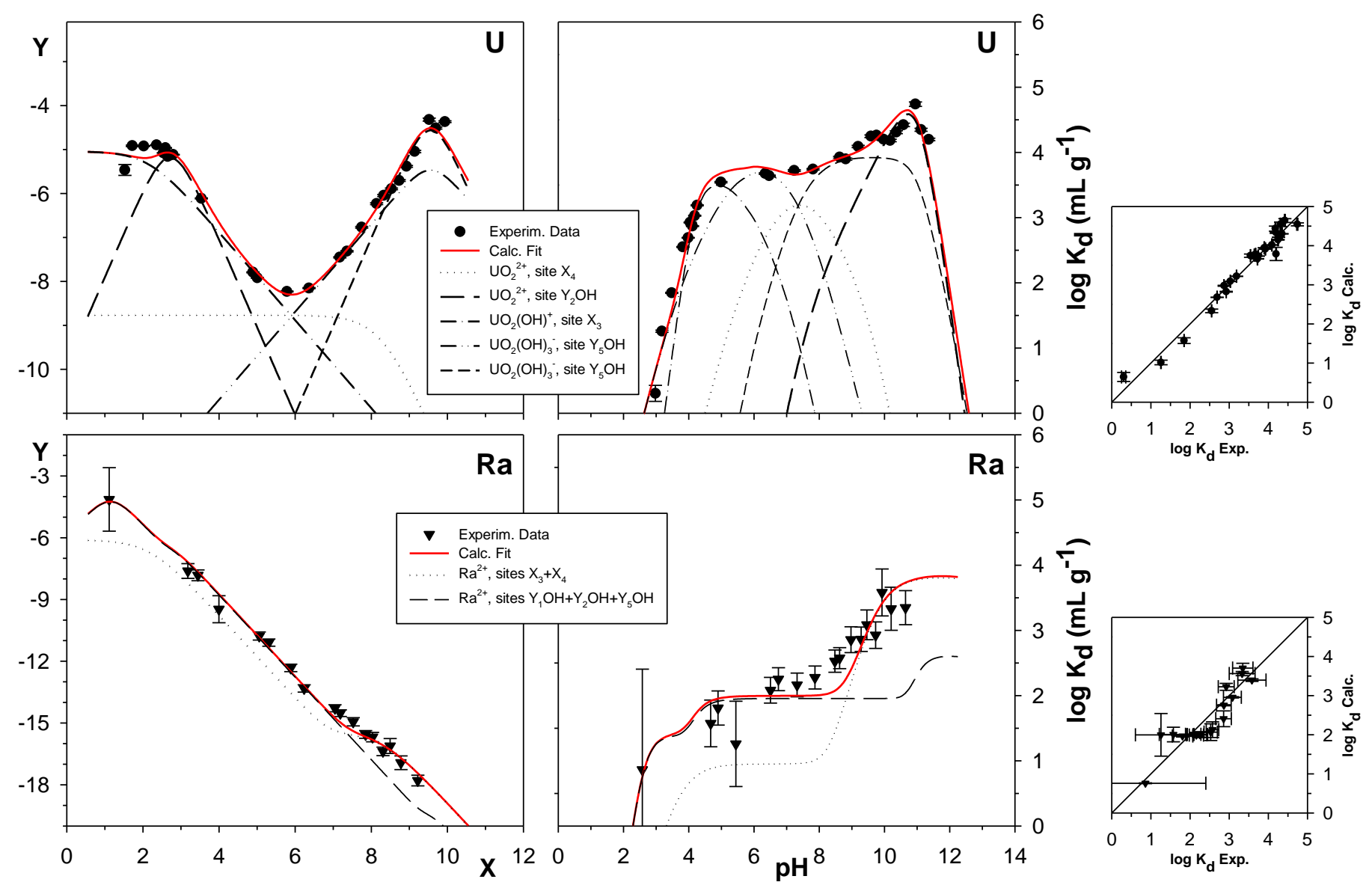

Figure 2.Left: Non-linear fitting of the $\mathrm{Y}=f(\mathrm{X})$ representation for trace $\mathrm{U}$ (top) and Ra (bottom) sorption. Centre: Fitting of experimental distribution coefficient $\left(\mathrm{K}_{\mathrm{d}}\right)$ for $\mathrm{U}($ top $)$ and $\mathrm{Ra}$ (bottom) sorption on K-kaolinite using Equation 13. In both graphs, the dotted and dashed lines correspond to individuallycalculated fit for the sorption of $U$ and $\mathrm{Ra}$ species on different sorption sites, while full red lines are the overall sum of $\mathrm{U}$ and $\mathrm{Ra}$ species and sorption sitesfits.Right: Comparison of experimental and calculated distribution coefficient of $\mathrm{U}$ (top) and Ra (bottom) on kaolinite. In all cases, the error bars represent $\pm 1 \sigma$. 

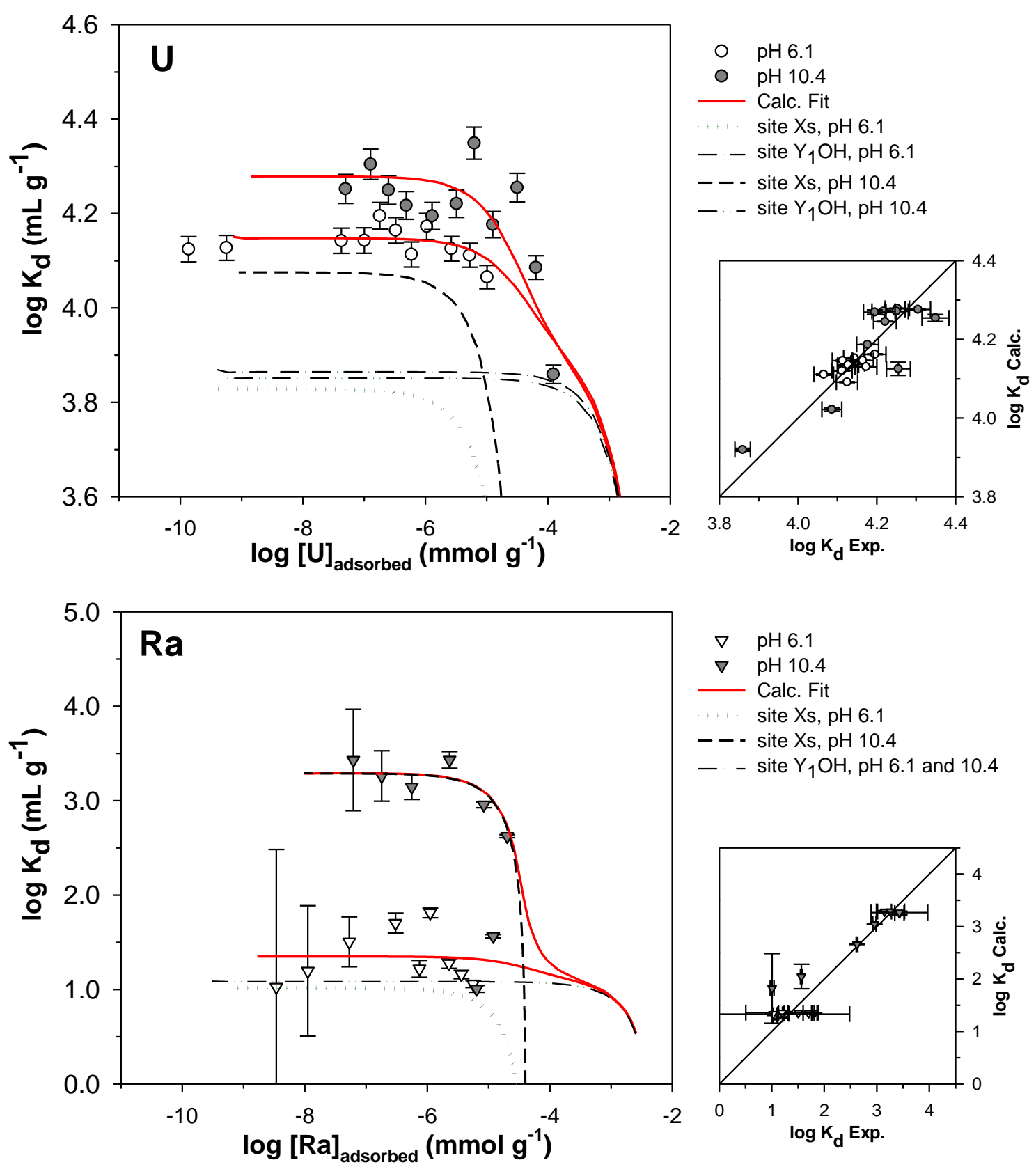

Figure 3. Adsorption isotherms of $\mathrm{U}$ (top) and $\mathrm{Ra}$ (bottom) on K-kaolinite. The distribution coefficient is represented as a function of adsorbed $\mathrm{U}$ or Ra concentration at pH 6.1 (empty symbols) and 10.4 (filled symbols), in the presence of $4.75 \cdot 10^{-2} \mathrm{M} \mathrm{K}$. The dotted and dashed lines correspond to the calculated adsorption isotherms on a minor sorption site, $\mathrm{Xs}$, and a major sorption sites, $\mathrm{Y}_{1} \mathrm{OH}$; and the full red lines are the overall $\mathrm{U}$ and $\mathrm{Ra}$ adsorption isotherms fittings. Graphs on the right are the comparisonof experimental and calculated distribution coefficients. In all cases, the error bars represent $\pm 1 \sigma$. 


\section{Tables}

Table 1. Type and concentration of major sorption sites, charge of the adsorbed species and the associated corrected selectivity coefficients, $K_{\left[M(O H)_{x}\right]^{m-x} /(m-x) \mathrm{H}}^{* i} K_{\left[M(O H)_{x}\right]^{m-x} /(m-x) O H}^{* j}$ describing the sorption of trace $\mathrm{U}(\mathrm{VI})$ and $\mathrm{Ra}(\mathrm{II})$ on $\mathrm{K}$-kaolinite in the presence of $5 \cdot 10^{-2} \mathrm{M} \mathrm{K}$. The values of the constants were determined after non-linear fitting of the $\mathrm{Y}=F(\mathrm{X}, \mathrm{Z})$ representation of the $\mathrm{U}$ and $\mathrm{Ra}$ sorption (Equation 14).

\begin{tabular}{cccccc}
\hline $\begin{array}{c}\text { Sorption sites } \\
\mathbf{X}_{i}, \mathbf{Y}_{j} \mathbf{O H}\end{array}$ & $\begin{array}{c}\text { Site conc. } \\
\left(\mathbf{m m o l ~ g} \mathbf{~ g}^{-1}\right)\end{array}$ & $\boldsymbol{K}_{\mathbf{K} / \mathbf{H}}^{* i}$ & $\begin{array}{c}\text { Charge } \\
(\boldsymbol{m}-\boldsymbol{x})\end{array}$ & Adsorbed Species & $\begin{array}{c}\text { Corrected selectivity } \\
\text { coefficients } \\
\boldsymbol{K}^{* i} / \boldsymbol{K}^{* \mathbf{j}}\end{array}$ \\
\hline $\mathrm{Y}_{2} \mathrm{OH}$ & $0.0190^{*}$ & $6.91 \mathrm{e}-03^{*}$ & 2 & $U O_{2}{ }^{2+}$ & $1.21 \pm 0.01$ \\
$\mathrm{X}_{3}$ & $0.0069^{*}$ & $6.91 \mathrm{e}-03^{*}$ & 1 & $U O_{2}(\mathrm{OH})^{+}$ & $(1.03 \pm 0.06) \cdot 10^{-3}$ \\
$\mathrm{X}_{4}$ & $0.0107^{*}$ & $5.21 \mathrm{e}-09^{*}$ & 2 & $\mathrm{UO}_{2}{ }^{2+}$ & $(1.98 \pm 0.07) \cdot 10^{-5}$ \\
$\mathrm{Y}_{5} \mathrm{OH}$ & $0.0089^{*}$ & $2.16 \mathrm{e}-09^{*}$ & -1 & $U O_{2}(\mathrm{OH})_{3}{ }^{-}$ & $(6.05 \pm 0.04) \cdot 10^{-3}$ \\
& & & -2 & $U O_{2}(\mathrm{OH})_{4}{ }^{2-}$ & $95.8 \pm 4.7$ \\
\hline $\mathrm{Y}_{1} \mathrm{OH}$ & $0.0108^{*}$ & $1.83^{*}$ & 2 & $R a^{2+}$ & $1292 \pm 20$ \\
$\mathrm{Y}_{2} \mathrm{OH}$ & $0.0190^{*}$ & $6.91 \mathrm{e}-03^{*}$ & 2 & $R a^{2+}$ & $(1.61 \pm 0.02) \cdot 10^{-2}$ \\
$\mathrm{X}_{3}$ & $0.0069^{*}$ & $6.91 \mathrm{e}-03^{*}$ & 2 & $R a^{2+}$ & $(1.65 \pm 0.10) \cdot 10^{-2}$ \\
$\mathrm{X}_{4}$ & $0.0107^{*}$ & $5.21 \mathrm{e}-09^{*}$ & 2 & $R a^{2+}$ & $(2.88 \pm 0.02) \cdot 10^{-14}$ \\
$\mathrm{Y}_{5} \mathrm{OH}$ & $0.0089^{*}$ & $2.16 \mathrm{e}-09^{*}$ & 2 & $R a^{2+}$ & $\leq 3.70 \cdot 10^{-14}$ \\
\hline
\end{tabular}

*values previously obtained (Reinoso-Maset and Ly, 2014)

Table 2.Type and concentration of sorption sites and their associated corrected selectivity coefficients $\left(K_{\mathrm{M} / m \mathrm{H}}^{*{ }^{*}}\right)$ describing the sorption of trace $\mathrm{U}(\mathrm{VI})$ and $\mathrm{Ra}(\mathrm{II})$ on $\mathrm{K}$-kaolinite in the presence of excess $\mathrm{K}$. Values were determined after non-linear fitting of the $\mathrm{U}$ and Ra isotherms at $\mathrm{pH} 10.4$ and 6.1 and $[\mathrm{K}]$ $=5 \cdot 10^{-2} \mathrm{M}$ using Equation 18 .

\begin{tabular}{ccccc}
\hline \multirow{2}{*}{$\begin{array}{c}\text { Sorption } \\
\text { Sites }\end{array}$} & $\begin{array}{c}\text { Concentration } \\
\left(\mathbf{m m o l ~ g}^{-1}\right)\end{array}$ & \multicolumn{3}{c}{ Corrected selectivity coefficients } \\
\cline { 3 - 5 } & & $\boldsymbol{K}_{\mathrm{UO2} / \mathbf{H}}^{* i}$ & $\boldsymbol{K}_{\mathrm{Ra} / \mathbf{H}}^{* i}$ & $\boldsymbol{K}_{\mathbf{K} / \mathbf{H}}^{* i}$ \\
\hline \multirow{2}{*}{$\mathrm{X}_{\mathrm{S}}$} & $0.000082 \pm 0.000002^{*}$ & $35.4 \pm 0.2(p H 6)$ & $0.121 \pm 0.004(p H 6)$ & $(12.7 \pm 0.5) \cdot 10^{-5}$ \\
& & $50.3 \pm 0.2(p H 10)$ & $17.5 \pm 0.2(p H 10)$ & \\
$\mathrm{Y}_{1} \mathrm{OH}$ & $0.0108 \pm 0.0001^{*}$ & $3.56 \cdot 10^{-5}$ & $1292 \pm 20^{*}$ & $(1.83 \pm 0.05)^{*}$ \\
\hline
\end{tabular}

*values takenfrom Table land Reinoso-Maset and Ly (2014) 
Table 3. Stoichiometry and associated corrected selectivity coefficientsof trace level U(VI) and Ra(II) adsorption equilibria on kaolinite.

\begin{tabular}{ll}
\hline Adsorption equilibria & $\log \boldsymbol{K}^{*}$ \\
\hline Uranium & \\
\hline $\mathrm{UO}_{2}^{2+}+2 \overline{\mathrm{X}_{\mathrm{s}} \mathrm{H}}-2 \mathrm{H}^{+} \leftrightarrow \overline{\left(\mathrm{X}_{\mathrm{s}}\right)_{2} \mathrm{UO}_{2}}$ & $1.55 / 1.70$ \\
$\mathrm{UO}_{2}^{2+}+2 \overline{\mathrm{Y}_{1} \mathrm{OH}}-2 \mathrm{H}^{+} \leftrightarrow \overline{\left(\mathrm{Y}_{1} \mathrm{O}\right)_{2} \mathrm{UO}_{2}}$ & 5.55 \\
$\mathrm{UO}_{2}^{2+}+2 \overline{\mathrm{Y}_{2} \mathrm{OH}}-2 \mathrm{H}^{+} \leftrightarrow \overline{\left(\mathrm{Y}_{2} \mathrm{O}\right)_{2} \mathrm{UO}_{2}}$ & 0.08 \\
$\mathrm{UO}_{2}^{2+}+\overline{\mathrm{X}_{3} \mathrm{H}}+\mathrm{H}_{2} \mathrm{O}-2 \mathrm{H}^{+} \leftrightarrow \overline{\left(\mathrm{X}_{3}\right) \mathrm{UO}_{2} \mathrm{OH}}$ & -2.99 \\
$\mathrm{UO}_{2}^{2+}+2 \overline{\mathrm{X}_{4} \mathrm{H}}-2 \mathrm{H}^{+} \leftrightarrow \overline{\left(\mathrm{X}_{4}\right)_{2} \mathrm{UO}_{2}}$ & -4.70 \\
$\mathrm{UO}_{2}^{2+}+\overline{\mathrm{Y}_{5} \mathrm{OH}}+2 \mathrm{H}_{2} \mathrm{O}-2 \mathrm{H}^{+} \leftrightarrow \overline{\left(\mathrm{Y}_{5}\right) \mathrm{UO}_{2}(\mathrm{OH})_{3}}$ & -2.22 \\
$\mathrm{UO}_{2}^{2+}+2 \overline{\mathrm{Y}_{5} \mathrm{OH}}+2 \mathrm{H}_{2} \mathrm{O}-2 \mathrm{H}^{+} \leftrightarrow \overline{\left(\mathrm{Y}_{5}\right)_{2} \mathrm{UO}_{2}(\mathrm{OH})_{4}}$ & 1.98 \\
\hline $\mathrm{Radium}$ & $-0.92 / 1.24$ \\
$\mathrm{Ra}^{2+}+2 \overline{\mathrm{X}_{\mathrm{S}} \mathrm{H}}-2 \mathrm{H}^{+} \leftrightarrow \overline{\left(\mathrm{X}_{\mathrm{s}}\right)_{2} \mathrm{Ra}}$ & 3.11 \\
$\mathrm{Ra}^{2+}+2 \overline{\mathrm{Y}_{1} \mathrm{OH}}-2 \mathrm{H}^{+} \leftrightarrow \overline{\left(\mathrm{Y}_{1} \mathrm{O}\right)_{2} \mathrm{Ra}}$ & -1.79 \\
$\mathrm{Ra}^{2+}+2 \overline{\mathrm{Y}_{2} \mathrm{OH}}-2 \mathrm{H}^{+} \leftrightarrow \overline{\left(\mathrm{Y}_{2} \mathrm{O}\right)_{2} \mathrm{Ra}}$ & -1.78 \\
$\mathrm{Ra}^{2+}+2 \overline{\mathrm{X}_{3} \mathrm{H}}-2 \mathrm{H}^{+} \leftrightarrow \overline{\left(\mathrm{X}_{3}\right)_{2} \mathrm{Ra}}$ & -11.54 \\
$\mathrm{Ra}^{2+}+2 \overline{\mathrm{X}_{4} \mathrm{H}}-2 \mathrm{H}^{+} \leftrightarrow \overline{\left(\mathrm{X}_{4}\right)_{2} \mathrm{Ra}}$ & -13.43 \\
$\mathrm{Ra}^{2+}+2 \overline{\mathrm{Y}_{5} \mathrm{OH}}-2 \mathrm{H}^{+} \leftrightarrow \overline{\left(\mathrm{Y}_{5} \mathrm{O}\right)_{2} \mathrm{Ra}}$ & \\
\hline
\end{tabular}

